\title{
Peningkatan kemampuan motorik halus melalui permainan menganyam dari bahan alam di taman kanak - kanak cahaya hati kabupaten pasaman barat
}

\author{
Meli Susanti \\ Universitas Negeri Padang \\ e-mail: mellysusanti827@gmail.com
}

\begin{abstract}
This study used Classroom Action Research conducted in Light Heart Kindergarten. This research was conducted for 2 months, namely as many as 2 cycles, namely cycle I consisted of 3 meetings and cycle II consisted of 3 meetings. Data collection with observations, interviews, and documentation were analyzed by percentage techniques. The results of observations on the initial conditions indicate that the children's fine motor skills are still low. The implementation of the first cycle of the first meeting until the third meeting showed an increase in the fine motor skills of the child, but had not been able to reach the KKM so that the second cycle was carried out. After the second cycle, the first meeting until the third meeting, there was a significant increase in the children's fine motor skills, especially in the aspect of children. They could move their fingers when weaving. Childhood Light Heart of West Pasaman.
\end{abstract}

Keywords: Fine motor skills, weaving games

\section{PENDAHULUAN}

Pendidikan anak usia dini adalah suatu upaya pembinaan yang ditujukan kepada anak sejak lahir sampai dengan usia enam tahun, yang dilakukan melalui pemberian rangsangan pendidikan untuk membantu pertumbuhan dan perkembangan jasmani dan rohani, agar anak memiliki kesiapan dalam memasuki pendidikan lebih lanjut (Rakimahwati, R, 2017). 
Pendidikan anak usia dini merupakan salah satu bentuk penyelenggaraan pendidikan yang menitik beratkan pada peletakan dasar kebeberapa arah yaitu pengembangan prilaku, pengembangan kemampuan dasar, serta fisik motorik. Taman Kanak - Kanak adalah pendidikan yang ditujukan bagi anak anak usia 4-6 tahun. Pada masa ini anak memasuki tahap praoperasional kongkrit dalam berfikir dari aktifitas belajar di Taman Kanak - kanak (Rakimahwati, R, 2014; Rakimahwati, R., \& Marlina, S, 2018).

Salah satu kemampuan dasar yaitu kemampuan fisik motorik. Kemampuan fisik motorik memegang peranan penting dalam perkembangan anak,namunperkembangan yang lain juga tidak kalah pentingnya.Pertumbuhan fisik anak diharapkan terjadi secara optimal karena secara langsung maupun tidak langsung akan mempengaruhi prilaku anak sehari hari.Perkembangan fisik anak meliputi perkembangan motorik kasar dan halus (Rakimahwati, R., Lestari, N. A., \& Hartati, S, 2018).

Perkembangan fisik anak melibatkan dua wilayah koordinasi motorik penting yaitu gerakan yang dikendalikan oleh otot-otot besar atau kasar dan dikendalikan oleh otot-otot kecil atau halus. Motorik halus sangat penting karena berpengaruh pada segi pembelajaran lainnya. Motorik halus penting karena ini nantinya akan dibutuhkan anak dari segi akademis tersebut seperti menulis, menggunting, menciplak, meronce, mewarnai dan menganyam.Penguasaan motorik halus penting bagi anak, karena seiring makin banyak keterampilan motorik yang dimiliki anak semakin banyak pula sosial yang dapat dilakukan anak serta semakin baik prestasi disekolah. Guru Taman Kanak - Kanak harus menciptakan suasana yang menyenangkan bagi anak dalam proses belajar mengajar, seperti kelengkapan media, memanfaatkan alam, membuat ide-ide dalam menciptakan permainan, dan juga metode guru yang bervariasi. Apalagi dalam proses pembelajaran motorik halus seperti menciplak, mewarnai, menjumput,membuat garis vertikal dan horizontal dan menganyam (Rakimahwati, R, 2018; Rakimahwati, R, 2014).

\section{METODE PENELITIAN}

Penelitian ini berbentuk penelitian tindakan kelas yaitu ragam penelitian pembelajaran yang berkonteks kelas dan dilaksanakan oleh guru untuk memecahkan masalah-masalah pembelajaran yang dihadapi oleh guru, memperbaiki mutu pembelajaran dan mencoba hal-hal baru dibidang pembelajaran demi peningkatan mutu dan hasil belajar.

Pada intinya Penelitian Tindakan Kelas merupakan suatu penelitian yang akar permasalahannya muncul di kelas, dan dirasakan oleh guru yang bersangkutan sehingga sulit dibenarkan jika ada anggapan bahwa permasalahan dalam penelitian tindakan kelas diperoleh dari persepsi atau lamunan dari seseorang peneliti, Jadi penelitian tersebut sangat bermanfaat sebagai upaya untuk memperbaiki proses pembelajaran di kelas.

Adapun jenis penelitian tindakan kelas menurut Arikunto (2007) mengemukakan penelitian tindakan kelas adalah penelitian yang dilakukan guru bekerjasama dengan peneliti atau melakukan dengan sendiri yang juga bertindak sebagai peneliti dikelas tempat peneliti mengajar dengan penekanan dan penyempurnaan peningkatan proses pembelajaran.

Subjek penelitian dilakukan dikelas B yang muridnya berjumlah 16 orang, laki-laki 5 orang, perempuan 11 orang. Pelaksanaan penelitian dilakukan pada semester I tahun ajaran 20018/2019 selama 2 bulan, tepatnya awal bulan November sampai Desember 2018.

Data yang diperoleh selama penelitian berlangsung dianalisis dengan teknik persentase, yaitu membandingkan yang muncul dari keseluruhan anak yang hadir dikalikan $100 \%$. Untuk melihat kecendrungan data, data ditampilkan dalam bentuk table dan diolah secara deskriptif.

Data yang diperoleh selama pembelajaran diolah dengan teknik persentase yang dikemukakan oleh Arikunto. Hasil yang dinilai untuk setiap pertemuan berdasarkan jumlah persentase anak yang terlibat dalam aktifitas pembelajaran dengan rumus

$$
\mathrm{P}=\mathrm{F} \quad \mathrm{X} 100 \%
$$

$$
\mathrm{N}
$$

Keterangan

$\mathrm{P}=$ Angka Persentase

$\mathrm{F}=$ Frekuensi yang sedang dicari persentasenya

$\mathrm{N}=$ Jumlah anak dalam satu kelas

\section{HASIL}


Berdasarkan penelitian yang telah peneliti lakukan, dimana menurut peneliti dari masing-masing siklus didapatkan bahwa melalui permainan menganyam dapat meningkatkan kemampuan motorik halus pada anak di Taman Kanak-kanak Cahaya Hati Kabupaten Pasaman Barat.Berkembangnya kemampuan motorik halus pada anak melalui perminan menganyam dari bahan alam pada masing-masing aspek dengan kriteria ketuntasan maksimum (KKM) sebesar 75\%, hal ini terlihat dari tingkat perkembangan anak dari masing-masing siklus yang terus meningkat.

Untuk lebih jelasnya analisis data peningkatan kemampuan motorik halus pada anak melalui permainan menganyam dari bahan alam dengan nilai berkembang sangat baik dapat dijabarkan sebagai berikut :

Tabel 1. Hasil Observasi Peningkatan Kemampuan Motorik Halus Anak Melalui Permainan Menganyam dari bahan alam di TK Cahaya Hati yang mendapatkan nilai berkembang sangat baik.

\begin{tabular}{|c|c|c|c|c|}
\hline No & Aspek yang dinilai & $\begin{array}{c}\text { Kondisi awal } \\
(\%)\end{array}$ & $\begin{array}{l}\text { Siklus I } \\
(\%)\end{array}$ & $\begin{array}{l}\text { Siklus II } \\
(\%)\end{array}$ \\
\hline 1 & $\begin{array}{l}\text { Anak mampu menggerakkan } \\
\text { jarinya saat menganyam }\end{array}$ & 0 & 12,5 & 93,75 \\
\hline 2 & $\begin{array}{l}\text { Anak dapat memasukkan daun } \\
\text { kedalam tempat anyaman }\end{array}$ & 0 & 18,75 & $87,5 \%$ \\
\hline 3 & $\begin{array}{l}\text { Anak dapat menganyam } \\
\text { dengan teknik anyaman tunggal }\end{array}$ & 0 & 12,5 & 81,25 \\
\hline
\end{tabular}

Hasil kondisi awal pada penelitian ini diketahui bahwa pada aspek pertama, anak mampu menggerakkan jari tangannya saat menganyam, yang mendapat nilai berkembang sangat baik (BSB) sebesar $0 \%$. Keadaan ini meningkat pada hasil siklus I yaitu $12,5 \%$ dan meningkat pada siklus II menjadi 93,75\%. Aspek kedua anak dapat memasukkan daun kedalam tempat anyaman pada kondisi awal tidak ada yang mendapat nilai berkembang sangat baik atau 0\%. Meningkat disiklus I menjadi 18,75\% dan meningkat menjadi 87,5\% pada siklus II. Aspek ketiga anak dapat menganyam dengan teknik anyaman tunggal pada kondisi awal tidak ada yang mendapat nilai berkembang sangat baik, meningkat menjadi $12,5 \%$ pada siklus I dan meningkat menjadi $81,25 \%$ pada siklus II.

\section{PEMBAHASAN}

Observasi yang dilakukan pada siklus I pertemuan pertama, kedua dan ketiga menunjukkan peningkataan kemampuan motorik halus anak.

Peningkatan yang terjadi pada siklus I adalah aspek 1, anak mampu menggerkakkan jarinya saat pembelajaran, terjadi peningkatan kemampuan sains, namun sebanyak 2 anak (12,5\%) mendapat nilai berkembang sangat baik, 3 anak (18,75\%) mendapatkan nilai berkembang sesuai harapan, 4 anak $(25 \%)$ mendapatkan nilai mulai berkembang dan 6 anak (37,5\%) mendapatkan nilai belum berkembang.

Menurut Oho Graha (2000) menganyam merupakan suatu kegiatan menjalin bahan yang berbentuk pita sehingga satu sama lainnya saling kuat menguatkan dan karena tekniknya timbulah motif yang berulang. Rian (2007) menyatakan bahwa anyaman adalah tenunan yang dibuat dari susunan benang, bilah, daun pandan dengan tindih menindih, silang menyilang atau dipersilangkan miring dari kiri kekanan dan sebaliknya.

Berdasarkan hasil penelitian, kemampuan motorik halus anak dapat meningkat dengan melakukan kegiatan menganyam secara bersama-sama. Dalam permainan air warna berjalan anak dibagi dalam beberapa kelompok dan anak akan diobservasi selama menganyam tersebut. Aspek yang diamati adalah anak mampu menggerakkan jari, anak dapat menganyam dengan teknik anyaman tunggal, dan anak bisa memasukkan daun kedalam tempat anyaman.

Berdasarkan hasil refleksi, maka peneliti membuat siklus II karena masih ada anak yang memiliki kemampuan belum berkembang (BB). Peningkatan kemampuan sains anak paling besar terlihat pada aspek pertama, aspek kedua dan aspek ketiga. Berdasarkan hasil observasi peneliti pada aspek pertama, anak mampu mengerkakkan jarinya saat pembelajaran,anak dapat menganyam dengan teknik anyaman tunggal, dan anak bisa memasukkan daun kedalam tempat anyaman bahwa terjadi peningkatan kemampuan motorik halus seiring dengan intensitas kegiatan yang dilakukan. Pendekatan oleh guru merupakan faktor penting anak untuk mendorong dan memotivasi anak dalam mengembangkan kemampuan dan kemauannya. 
Aspek pertama, anak mampu menggerakkan jari tangannya saat menganyam, pada pertemuan ke tiga diketahui 93,75\%, anak berkembang sangat baik dan 6,25\% anak berkembang sesuai harapan. Aspek kedua, yaitu anak dapat memasukkan daun kedalam tempat anyaman, anak saling membantu dan mengingatkan langkah-langkah yang harus dilakukan selama proses permainan dengan air warna berjalan. Pada akhir siklus II pertemuan ketiga didapatkan hasil bahwa anak yang mendapatkan nilai berkembang sangat baik 81,25, dan 18,75\% berkembang sesuai harapan. Aspek ketiga, anak dapat menganyam dengan teknik anyaman tungal didapatkan hasil $75 \%$ anak mendapatkan nilai berkembang sangat baik dan $25 \%$ anak berkembang sesuai harapan. Peningkatan kemampuan motorik halus pada aspek ini terlihat pada keinginan anak untuk segera merapikan peralatan yang digunakan dalam menganyam.

\section{SIMPULAN DAN SARAN}

Penelitian tindakan kelas tentang peningkatan kemampuan motorik halus anak melalui menganyam dari bahan alam di Taman Kanak - Kanak Cahaya Hati, dapat disimpulkan sebagai berikut:Terdapat peningkatan kemampuan motorik halus anak dengan menilai aspek kemampuan anak mampu menggerakan jari tanganya saat pembelajaran. Anak dapat menganyam dengan berbagai teknik. Anak bisa memasukan bahan yang akan dianyam kedalam anyaman. Hasil yang diperoleh aspek 1 diketahui bahwa pada kondisi awal terdapat $75 \%$ anak yang belum berkembang.

Berdasarkan kesimpulan di atas, ada beberapa saran yang ingin diuraikan sebagai berikut: Bagi guru Taman Kanak-Kanak dapat meningkatkan kemampuan motorik halus melalui permainan menganyam dari bahan alam semakin meningkat.Agar pembelajaran lebih menarik bagi anak-anak sebaiknya guru lebih kreatif dalam merancang kegiatan pembelajaran dengan menyajikan kegiatan yang lebih menarik.Kepada pihak Taman Kanak-kanak, hendaknya dapat melengkapi sarana dan prasarana untuk meningkatkan kemampuan menganyam anak. Bagi peneliti yang ingin melanjutkan penelitian ini diharapkan dapat meneliti lebih lanjut tentang menganyam dengan menciptakan yang lebih menarik dan mudah dipahami oleh anak-anak. Bagi pembaca diharapkan dapat menggunakan skripsi ini sebagai sumber ilmu pengetahuan guna menambah wawasan.

\section{DAFTAR PUSTAKA}

Arikunto, suharsimi. Dkk. (2006). Penelitian Tindakan Kelas. Jakarta: Bumi Aksara Defitri. (2012). Peningkatan kemampuan motorik halus anak melalui permainan membatik dengan tisu. Padang. Universitas Negri Padang

Hertiana. (2011). Meningkatkan kemampuan motorik halus anak melalui permainan karet gelang di TK Lillah Pasir Putih Tabing Padang. Padang. Universitas Negri Padang

Depdiknas. (2010).Kurikulum Pendidikan Anak Usia Dini 2013 . Jakarta

Elizar. (2008). Metode Demonstrasi Dalam Pembelajaran. Jakarta: Erlangga

Garha, Oho. (2004). Berbagi Motif Anyaman. Bandung: Angkasa.

Hartati. (2007). How To Be A Good Teacher and To Be A Good Mother. Seri Panduan Pendidikan Anak Usia Dini

Kementrian Pendidikan Nasional. (2010). Kurikulum Taman Kanak-Kanak, Jakarta:Direktorat Pendidikan Anak Usia Dini.

Masitoh , dkk. (2009). Pendekatan Belajar Aktif Di Taman Kanak- Kanak. Jakarta: Depdiknas Dikjen Pendidikan Tinngi Direktorat Pembinaa Pendidikan Tenaga Kependidikan Dan Ketenagaan Perguruan Tinggi.

M. Ramli. (2005). Pendampingan Perkembangan Anak Usia Dini. Jakarta :Depdiknas Dikjen Pendidikan Tinggi Direktorat Pembinaan Pendidikan Tenaga Kependidikan dan Ketenagaan Perguruan Tinggi

MS Sumantri. (2005). Pengembangan Keterampilan Motorik Anak Usia Dini. Yokyakarta : Kalimedia

Mulyasa, H.E. (2012). Manajemen PAUD.Bandung: PT Remaja Rosdakarya

Nugraha, Ali. (2008). Metode Pengembangan Sosial Emosional. Jakarta : Universitas Terbuka

Rakimahwati, R. (2018). Pelatihan Pembuatan Boneka Jari Bergambar dalam Meningkatkan Kemampuan Membaca Anak Usia Dini Di Kecamatan V Koto Kampung dalam Kabupaten Padang Pariaman. Early Childhood: Jurnal Pendidikan, 2(2b), 1-11. 
Rakimahwati, R. (2017). Interactive Game Influences Based on Inquiry Learning Model Towards The Ability of Reading in Kindergarten in Padang. In International Conference of Early Childhood Education (ICECE 2017). Atlantis Press.

Rakimahwati, R. (2014). Character Development through Dance Learning in an Early Childhood Setting. Indonesian Journal of Early Childhood Education Studies, 3(2), 102-107.

Rakimahwati, R. (2014). The Effectiveness of a Crossword Puzzle Game in Improving Numeracy Ability of Kindergarten Children. Asian Social Science, 10(5), 79.

Rakimahwati, R., Lestari, N. A., \& Hartati, S. (2018). Pengaruh Kirigami Terhadap Kemampuan Motorik Halus Anak di Taman Kanak-Kanak. Jurnal Obsesi: Jurnal Pendidikan Anak Usia Dini, 2(1), 102-110.

Rakimahwati, R., \& Marlina, S. (2018). Pengaruh Media Busy Book Terhadap Kemampuan Berhitung Anak Usia Dini Di Taman Kanak-Kanak Fadhilah Amal 3 Padang. Jurnal Usia Dini, 4(2), 8-17. 